\title{
Hubungan Pengetahuan, Sikap, dengan Partisipasi Pasangan Usia Subur dalam Program KB di Desa Huta Padang Sayur Maincat Kecamatan Kotanopan Kabupaten Mandailing Natal Serta Implikasinya dalam Bimbingan Dan Konseling
}

\author{
Harun Arrasyd ${ }^{1}$, Asmaryadi $^{2}$, Khairul Amri', \\ ${ }^{1}$ Dosen Bimbingan dan Konseling, UMTS Padangsidimpuan \\ (harun.arrasyd@um-tapsel.ac.id) \\ ${ }^{2}$ Dosen Bimbingan dan Konseling, UMTS Padangsidimpuan \\ (asmaryadi@um-tapsel.ac.id) \\ ${ }^{3}$ Dosen Bimbingan dan Konseling, UMTS Padangsidimpuan \\ (khairul.amri@um-tapsel.ac.id)
}

\begin{abstract}
This study aims to obtain, process, analyze, and discuss data on the relationship of knowledge and attitudes with the participation of fertile couples in family planning programs in the village of Huta Padang Sayur Maincat, Kotanopan District, Mandailing Natal District. Indicators of the participation of fertile age couples in family planning programs are participation in family planning programs and willingness to contribute to family planning programs, knowledge indicators, namely knowledge of family planning, knowledge of vision and mission and scope of family planning programs, knowledge of the goals and benefits of family planning programs, knowledge of family planning and attitude indicators, namely cognitive, affective and connotive.

The study was conducted using quantitative methods and the type of this research used was descriptive correlational. According to Sugiyono (2009) correlational research is research whose nature asks the relationship between two or more variables. The selection of descriptive correlational research is based on research that wants to examine and see the degree of relationship between knowledge and attitudes with the participation of couples of reproductive age in family planning programs individually and together in the village of Huta Padang Sayur Maincat, Kotanopan District, Mandailing Natal District.

The results of this study are expected to be a material and source of knowledge for the community, especially the Fertile Age Couples regarding Family Planning, for the Guidance and Counseling Study Program to be the Handbook especially for Community Counseling, Divorce and Referral courses. The results of this study will also be displayed at national seminars or national scientific publications and as teaching materials.
\end{abstract}

Keyword: Knowledge, Attitude, KB

\begin{abstract}
Abstrak: Penelitian ini bertujuan untuk mendapatkan, mengolah, menganalisis, dan membahas data tentang hubungan pengetahuan dan sikap dengan partisipasi pasangan usia subur dalam dalam program KB di desa Huta Padang Sayur Maincat Kecamatan Kotanopan Kabupaten Mandailing Natal. Indikator Partisipasi Pasangan Usia Subur dalam Program KB yaitu keikutsertaan dalam program $\mathrm{KB}$ dan kesedian memberikan sumbangan dalam program $\mathrm{KB}$, indikator Pengetahuan yaitu pengetahuan tentang $\mathrm{KB}$, pengetahuan tentang visi dan misi dan ruang lingkup program $\mathrm{KB}$, pengetahuan tentang tujuan dan manfaat program $\mathrm{KB}$, pengetahuan kontrasepsi KB dan indikator Sikap yaitu kognitif, afektif dan konotif.

Penelitian dilakukan menggunakan metode kuantitatif dan Jenis penelitian ini yang digunakan adalah deskriptif korelasional. Menurut Sugiyono (2009) penelitian korelasional adalah penelitian yang sifatnya menanyakan hubungan antara dua variabel atau lebih. Pemilihan jenis penelitian deskriptif korelasional didasarkan dari penelitian yang ingin mengkaji dan melihat derajat hubungan pengetahuan dan sikap dengan partisipasi pasangan usia subur dalam program KB secara sendiri-sendiri dan secara bersama-sama di desa Huta Padang Sayur Maincat Kecamatan Kotanopan Kabupaten Mandailing Natal.
\end{abstract}


Hasil penelitian ini diharapkan menjadi bahan dan sumber pengetahuan bagi masyarakat terutama Pasangan Usia Subur mengenai KB, bagi Program Studi Bimbingan dan Konseling menjadi Handbook terutama mata kuliah Konseling Masyarakat, Talak dan Rujuk. Hasil penelitian ini juga akan ditampilkan pada seminar nasional atau publikasi ilmiah nasional dan sebagai bahan ajar.

Kata Kunci: Pengetahuan, Sikap, KB.

\section{PENDAHULUAN}

Keluarga berencana sebagai suatu gerakan khusus yang dihubungkan dengan usaha pengaturan kelahiran anak, jarak dan usia ideal melahirkan, mengatur kehamilan, perlindungan, dan bantuan sesuai dengan hak reproduksi untuk mewujudkan keluarga yang berkualitas. Motivasi yang lebih luas dan demi kepentingan kesehatan, maka keluarga berencana sebagai program nasional telah ditetapkan merata di seluruh tanah air dengan didukung oleh penyediaan fasilitas kesehatan yang memadai, tetapi didukung dari segenap warga masyarakat khususnya pasangan usia subur dalam program keluarga berencana adalah faktor yang sangat penting. Secara umum sasaran dari program $\mathrm{KB}$ adalah pasangan usia subur. Pasangan usia subur adalah pasangan suami istri yang berstatus menikah yang istrinya berusia 15-49 tahun ( UU No. 52 Tahun 2009).

Penduduk merupakan modal dasar dan sekaligus merupakan faktor dominan pembangunan nasional. Hal ini berarti bahwa jumlah penduduk yang besar dengan pertumbuhan penduduk yang cukup tinggi, apabila dapat dikendalikan atau dibina akan merupakan modal pembangunan yang besar. Indonesia sebagai negara yang sedang berkembang tidak luput dari berbagai masalah, salah satunya adalah masalah di bidang kependudukan yaitu: 1) Jumlah penduduk yang cukup besar, 2) Persebaran penduduk yang tidak merata, 3) Struktur umum penduduk relatif mudah, 4) Kelahiran dan kematian yang cukup tinggi.

Partisipasi pasangan usia subur dalam program KB dipengaruhi juga oleh pengetahuan dan sikap/perilaku. Rendahnya pengetahuan pasangan usia subur tersebut mempengaruhi persepsi pasangan usia subur tentang penggunaan alat kontrasepsi, karena salah satu yang menentukan persepsi seseorang adalah pengetahuan yang dimiliki. Seseorang yang memiliki pengetahuan baik tentang sesuatu akan memiliki persepsi yang lebih positif terhadap hal tersebut. Seseorang yang memiliki persepsi positif tentang sesuatu akan membuat individu tersebut akan memiliki sikap dan perilaku yang positif juga terhadap hal tersebut. (Lestari, 2007).

Suksesnya suatu program KB tergantung dari partisipasi pasangan usia subur dalam program tersebut, sehingga dalam posisi ini peran aktif masyarakat sangat penting. Program KB dicanangkan dalam rangka usaha pemerintah untuk membangun manusia Indonesia yang berkualitas (Lestari, 2007).

Fenomena penduduk seperti ini apabila tidak diatasi, maka jumlah penduduk akan terus bertambah tiap tahunnya, sehingga diperlukan adanya partisipasi masyarakat dalam pengendalian pertumbuhan penduduk agar tidak menyebabkan kompleksitas masalah. Salah satu caranya untuk mengatasi masalah tersebut dengan program keluarga berencana. Keluarga berencana merupakan upaya peningkatan kepedulian masyarakat dalam mewujudkan keluarga kecil yang bahagia sejahtera.

Menurut Davis dalam Suwignyo (2009) kata partisipasi secara etimologis berasal dari bahasa Inggris "participation" yang berarti mengambil bagian, participator dimaknai sebagai yang mengambil bagian atau sering disebut dalam bahasa umum sebagai keikutsertaan. Partisipasi sering dikatakan sebagai peran serta atau keikutsertaan mengambil bagian dalam kegiatan tertentu, karena terdapat keterlibatan mental/pikiran dan emosi/perasaan seseorang dalam situasi kelompok yang mendorong partisipan untuk memberikan sumbangan kepada kelompok dalam usaha mencapai tujuan serta tanggung jawab terhadap usaha mencapai tujuan yang bersangkutan. Hal yang terakhir senada dengan batasan yang 
diberikan dalam batang tubuh UU 25/2004 tentang Sistem Perencanaan Pembangunan Nasional, Pasal 2 ayat 4 huruf d bahwa partisipasi merupakan keikutsertaan masyarakat untuk mengakomodasi kepentingan mereka dalam proses penyusunan rencana pembangunan.

Allport (Sastropoetro, 1988) menyatakan seseorang yang berpartisipasi sebenarnya mengalami keterlibatan dirinya/egonya yang sifatnya lebih daripada keterlibatan dalam pekerjaan atau tugas saja". Davis (dalam Sastropoetro 1988) mengemukakan definisinya adalah "Participation can be defined as mental and emotional involvement of a person in group situation which encourages him contribute to group goal and share responsibility in them". Adapun faktorfaktor yang Mempengaruhi Partisipasi

1) Pendidikan, kemampuan membaca dan menulis, kemiskinan, kedudukan sosial, dan percaya terhadap diri sendiri

2) Kecenderungan untuk menyalah artikan motivasi, tujuan dan kepentingan organisasi penduduk yang biasanya mengarah kepada timbulnya persepsi yang salah terhadap keinginan dan motivasi.

3) Tersedianya kesempatan kerja yang lebih baik di luar pedesaan.

4) Tidak terdapatnya kesempatan untuk berpartisipasi dalam berbagai program pembangunan. Pengetahuan adalah segala sesuatu yang diketahui; kepandaian (Kamus Besar Bahasa Indonesia, 2003). Menurut Notoatmodjo (2005) Pengetahuan merupakan hasil dari tahu, yang terjadi setelah orang melakukan penginderaan terhadap objek tertentu. Penginderaan terjadi melalui panca indra manusia, yakni indera penglihatan, pendengaran, penciuman, rasa, dan raba. Sebagian besar pengetahuan diperoleh dari mata dan telinga.

Menurut Sjamsuri (1989) pengetahuan merupakan pedoman dalam membentuk tindakan seseorang. Pengetahuan adalah apa yang kita tahu tentang alam lingkungan kita. Manfaat dari pengetahuan yaitu untuk membantu memecahkan masalah-masalah hidup yang dihadapinya. Adapun Faktor-faktor yang Mempengaruhi Pengetahuan adalah Pendidikan, Informasi, Sosial budaya dan ekonomi, Lingkungan, Pengalaman dan Usia.

Sikap adalah reaksi yang masih tertutup, tidak dapat dilihat secara langsung sehingga sikap hanya dapat ditafsirkan dari perilaku yang tampak (Notoatmojo, 2005). Pengertian lain sikap merupakan kesiapan untuk bereaksi terhadap suatu objek dengan cara tertentu serta merupakan respon evaluatif terhadap pengalaman kognitif, reaksi afeksi, kehendak dan perilaku masa lalu. Sikap akan mempengaruhi proses berpikir, respon afeksi, kehendak dan perilaku berikutnya. Jadi sikap merupakan respon evaluatif didasarkan proses evaluasi diri, yang disimpulkan berupa penilaian positif atau negatif yang kemudian mengkristal sebagai potensi reaktif terhadap objek. Adapun Faktor-faktor yang Mempengaruhi Sikap adalah pertama, Faktor yang terdapat dalam pribadi manusia itu sendiri. Faktor ini berupa selectivity atau daya pilih seseorang untuk menerima atau mengolah pengaruh yang datang dari luar. Kedua, Faktor yang terdapat diluar pribadi manusia. Faktor ini berupa interaksi sosial di luar kelompok.

\section{METODE}

Jenis penelitian ini yang digunakan adalah deskriptif korelasional. Menurut Sugiyono (2009) penelitian korelasional adalah penelitian yang sifatnya menanyakan hubungan antara dua variabel atau lebih. Pemilihan jenis penelitian deskriptif korelasional didasarkan dari penelitian yang ingin mengkaji dan melihat derajat hubungan pengetahuan dan sikap dengan partisipasi pasangan usia subur dalam program KB secara sendiri-sendiri dan secara bersama-sama di Desa Huta Padang Sayur Maincat Kecamatan Kotanopan Kabuaten Mandailing Natal.

Populasi adalah sebagai wilayah generalisasi yang terdiri atas objek/subjek yang mempunyai kualitas 
dan karakteristik tertentu ditetapkan oleh peneliti untuk dipelajari dan kemudian ditarik kesimpulannya. Populasi dalam penelitian ini adalah pasangan usia subur di Desa Huta Padang Sayur Maincat Kecamatan Kotanopan Kabupaten Mandailing Natal.

Sampel adalah bagian dari jumlah dan karakteristik yang dimiliki oleh populasi tersebut (Sugiyono, 2006). Sampel dalam penelitian ini diambil dengan menggunakan purposive sampling yaitu sampel yang dipilih secara cermat dengan mengambil orang atau objek penelitian yang selektif dan mempunyai ciri-ciri spesifik. Hal ini dikarenakan, sampel yang digunakan memiliki ciri khusus yaitu pasangan usia subur.

Untuk mendapatkan data dan informasi yang sesuai dengan tujuan penelitian, maka penulis menggunakan teknik pengumpul data sebagai berikut:

Studi dokumentasi adalah teknik pengumpulan data yang diambil dari berbagai sumber data dokumen, brosur, peraturan - peraturan atau data dari instansi pemerintah setempat. Dalam penelitian ini, penulis mengumpulkan data yang mendukung penelitian. Datadata tersebut didapat dari instansi terkait.

Angket adalah teknik penelitian berupa penyebaran instrumen berisi sejumlah pertanyaan yang harus diisi responden. Angket merupakan alat yang digunakan untuk mengumpulkan data kuantitatif dan dapat juga untuk mengumpulkan informasi yang kualitatif

\section{HASIL PENELITIAN DAN PEMBAHASAN}

Bentuk hubungan ketiga variabel tersebut dapat dinyatakan dengan persamaan regresi $\hat{Y}=7,303+0,445 X_{1}+$ $0,445 \mathrm{X}_{2}$. Persamaan ini perlu diuji tingkat keberatiannya dengan uji $\mathrm{F}$.
Tabel 19.Uji Persamaan Regresi $X_{1}$ dan $X_{2}$ dengan $Y$

\begin{tabular}{|l|r|r|r|r|r|}
\hline Model & $\begin{array}{l}\text { Sum of } \\
\text { Squares }\end{array}$ & df & $\begin{array}{l}\text { Mean } \\
\text { Squar } \\
\text { e }\end{array}$ & F & Sig. \\
\hline $1 \quad \begin{array}{l}\text { Regres } \\
\text { sion }\end{array}$ & 723.123 & 2 & 361.56 & 6.077 & .00 \\
2 & & $3^{\mathrm{a}}$ \\
$\begin{array}{l}\text { Residu } \\
\text { al }\end{array}$ & 5652.22 & 95 & 59.497 & & \\
Total & 6375.34 & 97 & & & \\
& 7 & & & & \\
\hline
\end{tabular}

Sumber : Pengolahan Data Primer 2018

Pada tabel diatas bahwa $\mathrm{F}_{\text {hitung }}=$ 6.077dengan sig $0,000<$ alpha 0,005 dan $F_{\text {tabel }(0,05 ; 2 ; 95)}$ diperoleh sebesar 3,09, dengan demikian $F_{\text {hitung }}$ lebih besar dari $\mathrm{F}_{\text {tabel. }}$. Model persamaan regresi $\hat{\mathrm{Y}}=7,303$ $+0,445 X_{1}+0,445 X_{2}$ adalah signifikan pada taraf kepercayaan $95 \%$. Model persamaan tersebut mengandung arti bahwa apabila secara bersama-sama pengetahuan dan sikap ditingkatkan sebesar satu skor, maka akan terjadi kecenderungan peningkatan partisipasi pasangan usia subur dalam program KB dengan konstanta sebesar 7,303.

Berdasarkan analisis di atas dapat disimpulkan bahwa pengetahuan dan sikap berkontribusi dengan partisipasi pasangan usia subur dalam program KB. Hipotesis ketiga yang menyatakan terdapat hubungan yang signifikan antara pengetahuan dan sikap dengan partisipasi pasangan usia subur dalam program $\mathrm{KB}$ dapat diterima dan telah teruji secara empiris pada taraf kepercayaan 95\%. Kontribusi variabel pengetahuan dan sikap dengan partisipasi pasangan usia subur dalam program $\mathrm{KB}$ adalah $11,3 \%$.

Berdasarkan hasil penelitian di atas selanjutnya diperoleh pembahasan sebagai berikut:

Pertama: Hubungan pengetahuan dengan partisipasi pasangan usia subur dalam program KB di Desa Huta Padang Sayur Maincat Kec. Kotanopan. Pada hasil analisis korelasi antara variabel pengetahuan PUS $\left(\mathrm{X}_{1}\right)$ dengan variabel partisipasinya dalam program 
KB (Y) didapatkan $r_{\text {hitung }} 0,250>r_{\text {tabel }} 0,197$ yang menyatakan bahwa ada hubungan antara pengetahuan dengan partisipasi pasangan usia subur dalam program $\mathrm{KB}$ dengan kontribusi yang diberikan sebesar $6,2 \%$. Sesuai hasil uji t diperoleh $t_{\text {hitung }} 2,525>t_{\text {tabel }} 1,661$ dapat disimpulkan bahwa pengetahuan dengan partisipasi pasangan usia subur dalam program KB memiliki hubungan yang signifikan.

Hal ini berarti pengetahuan mempunyai peranan penting dalam partisipasi pasangan usia subur atau keikutsertaannya dalam program KB. Dalam hal ini pasangan usia subur belum memahami arti penting dari program KB tersebut. Hasil pengolahan data tersebut terkait dengan pendapat Ross (1960) yang menyatakan ada tiga prakondisi tumbuhnya partisipasi salah satunya yaitu mempunyai pengetahuan yang luas dan latar belakang yang memadai. Dengan demikian dapat dinyatakan bahwa pengetahuan pasangan usia subur memiliki peranan penting dalam partisipasin atau keikutsertaan dalam program KB. Diperkuat oleh Temuan Hakim (2013) Faktor pengetahuan dalam $\mathrm{KB}$ berperan kuat dalam keikutsertaan ber-KB khususnya yang berhubungan dengan keefektifan alat kontrasepsi dan efek samping yang ditimbulkan dari pemakaian alat kontrasepsi tersebut.

Kedua: Hubungan sikap dengan partisipasi pasangan usia subur dalam program KB di Desa Huta Padang Sayur Maincat Kec. Kotanopan. Hasil analisis dilakukan dengan uji korelasi product moment antara variabel sikap $\left(\mathrm{X}_{2}\right)$ dengan variabel partisipasi pasangan usia subur dalam program $\mathrm{KB}(\mathrm{Y})$ didapatkan $\mathrm{r}_{\text {hitung }}$ $0,279>\mathrm{r}_{\text {tabel }} 0,197$ yang menyatakan bahwa ada hubungan antara sikap dengan partisipasi pasangan usia subur dalam program KB dengan kontribusi yang diberikan sebesar 7,8\% . Sesuai hasil uji $\mathrm{t}$ diperoleh $\mathrm{t}_{\text {hitung }} 2.851>\mathrm{t}_{\text {tabel }} 1,661$ dapat disimpulkan bahwa sikap dengan partisipasi pasangan usia subur dalam program KB memiliki hubungan yang signifikan.

Temuan dalam penelitian ini menjelaskan bahwa sikap berperan penting dalam partisipasi pasangan usia subur atau keikutsertaannya dalam program KB. Hasil pengolahan data tersebut terkait dengan pendapat Ross (1960) yang menyatakan ada tiga prakondisi tumbuhnya partisipasi salah satunya yaitu kemampuan mengambil tindakan dan bertindak efektif. Ini sesuai dengan komponen sikap salah satu yaitu kecenderungan untuk bertidak. Temuan Ahmadi (2007) yang menyatakan ciri-ciri sikap pada umumnya mempunyai segi-segi motivasi dan emosi. Hal ini sesuai dengan elemen-elemen dalam partisipasi yaitu motivasi yang mana persyaratan utama pasangan usia subur adalah motivasi, tanpa motivasi masyarakat sulit untuk berpartisipasinya di segala program. Seseorang yang berpartisipasi dapat menerima manfaat program KB tersebut dikarenakan memilki sikap yang positif, orang yang memilki sikap positif menghasilkan tingkah laku seperti mengikuti program $\mathrm{KB}$.

Ketiga: Hubungan pengetahuan dan sikap dengan partisipasi pasangan usia subur dalam program KB di Desa Huta Padang Sayur Maincat Kec. Kotanopan. Hasil korelasi ganda antara variabel pengetahuan $\left(\mathrm{X}_{1}\right)$ dan sikap $\left(\mathrm{X}_{2}\right)$ dengan partisipasi pasangan usia subur dalam program KB (Y) didapatkan nilai koefisien korelasi adalah 0,337 atau $\left(\mathrm{r}_{\mathrm{YX} 1, \mathrm{X} 2}=0,337\right)$ dengan nilai probabilitas (sig. $\mathrm{F}$ change) $=0,003$ karena nilai sig. $F$ change $<0,05$ maka dapat disimpulkan bahwa pengetahuan dan sikap berhubungan simultan dan signifikan dengan partisipasi pasangan usia subur dalam program KB. Determinasi $\left(\mathrm{R}^{2}\right)$ didapatkan nilai sebesar 0,113 sehingga variabel pengetahuan dan sikap memberikan kontribusi $11,3 \%$ sedangkan sisanya ditentukan oleh variabel lain.

Pengetahuan dan sikap merupakan faktor predisposisi dan menjadi motivasi dalam berperilaku atau bertindak (Notoatmomodjo, 2007). Pengetahuan dan sikap positif akan menjadi daya pendorong yang akan menggerakkaan seseorang untuk melakukan sesuatu demi tercapainya tujuan yang telah ditetapkan. Temuan ini sesuai dengan tujuan KIE (Komunikasi Informasi Edukasi) dalam program KB yaitu untuk mendorong terjadinya proses perubahan prilaku kearah positif, peningkatan pengetahuan, sikap dan pratik masyarakat secara wajar sehingga masyarakat melaksanakan secara mantap sebagai prilaku yang sehat dan bertanggung jawab.

\section{SIMPULAN}

Penelitian ini bertujuan untuk keterkaitan hubungan pangetahuan dengan partisipasi pasangan usia subur dalam program $\mathrm{KB}$, sikap dengan partisipasi pasangan usia 
subur dalam program KB dan pengetahuan dan sikap dengan partisipasi pasangan usia subur dalam program KB. Berdasarkan hasil penelitian maka kesimpulan yang diambil dalam penelitian ini adalah:

1. Pada variabel pengetahuan $\left(X_{1}\right)$ dan sikap $\left(\mathrm{X}_{2}\right)$ dengan partisipasi pasangan usia suburdalam program KB (Y) adalah data berdistribusi normal, karena histrogramnya berbentuk seperti lonceng.

2. Terdapat hubungan pengetahuan dengan partisipasi pasangan usia subur dalam program KB sebesar $r_{\text {hitung }} 0,250>r_{\text {tabel }}$ 0,197 . Sesuai hasil uji $t$ diperoleh $t_{\text {hitung }}$ $2,525>t_{\text {tabel }} 1,661$ sehingga pengetahuan dengan partisipasi pasangan usia subur dalam program KB memiliki hubungan yang signifikan dan kontribusi yang diberikan sebesar $6,2 \%$ terhadap partisipasi pasangan usia subur dalam program KB.

3. Teradapat hubungan sikap dengan partisipasi pasangan usia subur dalam program KB sebesar $\mathrm{r}_{\text {hitung }} 0,279>\mathrm{r}_{\text {tabel }} 0,197$. Sesuai hasil uji $t$ diperoleh $t_{\text {hitung }} 2.851>t_{\text {tabel }}$ 1,661 sehingga sikap dengan partisipasi pasangan usia subur dalam program KB memiliki hubungan yang signifikan dan kontribusi yang diberikan sebesar 7,8\% terhadap partisipasi pasangan usia subur dalam program KB.

4. Terdapat hubungan pengetahuan dan sikap secara bersama-sama dengan partisipasi pasangan usia subur dalam program KB sebesar nilai $\mathrm{R}$ sebesar 0,113 dengan nilai probabilitas (sig. $\mathrm{F}$ change) $=0,003$ karena nilai sig. $F$ change $<0,05$ maka pengetahuan dan sikap dengan partisipasi pasangan usia subur dalam program KB memiliki hubungan yang signifikan dan kontribusi yang diberikan sebesar 11,3\% terhadap partisipasi pasangan usia subur dalam program KB.

\section{DAFTAR RUJUKAN}

Abidin dan Suyasa. 2003. Mengenal Diri Pribadi. Jakarta: ANS Sungguh Bersaudara.

A. Muri Y. 2007. Metodologi Penelitian. Padang: UNP Press.

Ahmadi, Abu. 2007. Psikologi Sosial. Rineka Cipta. Jakarta.Anggaraini, Yetti. 2012.

Badan Pusat Statistik Mandailing Natal Tahun 2017
Bimo W. 2002. Psikologi Kependidikan. Bandung: Rosda.

Hakim, Ari Rahman. 2013. Jurnal. FaktorFaktor Yang Mempengaruhi Partisipasi Pasangan Usia Subur Dalam Program $\mathrm{Kb}$ Di Kecamatan Kauman Kabupaten Ponorogo. Pendidikan Geografi. Universitas Negeri Surabaya.

Muhibbin S. 2010. Psikologi Pendidikan Suatu Pendekatan Baru. Bandung: Rosda Karya.

Prayitno. 2004. "Layanan Bimbingan dan Konseling Kelompok (Dasar dan Profil)" Jakarta: Ghalia Indonesia.

Prayitno. 1995. Jenis layanan dan kegiatan pendukung konseling. Padang: FIP-UNP.

Romlah. 2001. Bimbingan konseling. Jakarta : Balai Pustaka.

Tohirin. 2009. Bimbingan dan Konseling Di Sekolah dan Madrasah (Berbasis Integrasi). Jakarta: RajaGrafindo Persada.

Notoatmodjo, Sukidjo. 2010. Metodologi Promosi Kesehatan Teori dan Aplikasi. Rineka Cipta. Jakarta.

Notoatmodjo, Sukidjo. 2007. Promosi Kesehatan dan Ilmu Prilaku. Rineka Cipta. Jakarta.

Puskesmas Kecamatan, Kotanopan, Kabupaten Mandailing Natal

Riduwan dan Sunarto. 2011. Statistik untuk pendidikan, sosial, ekonomi, komunikasi dan bisnis. Alfabeta. Bandung.

Sastropoerto, Santoso. 1988. Partisipasi, Komunikasi, Persuasi dan Disiplin dalam Pembangunan Nasional. Alumni. Bandung.

Silalahi, Ulber. 2012. Metode Penelitian Sosial. PT Rafika Aditama. Bandung.

Sjamsuri. 1989. Pengantar Teori Pengetahuan.Jakarta: Depdikbud.

Sugiyono. 2012. Metode Penelitian Kuantitatif kualittatif dan $R \& D$. Alfabeta. Bandung.

Suharsimi, Arikunto. 2010. Prosedur Penelitian Suatu Pendekatan Praktik.PT Rineka Cipta. Jakarta.

UU RI No.52 Tahun 2009. Tentang Perkembangan Kependudukan Dan Pembangunan Keluarga.

UPT dinas Pendidikan kec. Kotanopan dan portal kemendikbud (dapo.dikdasmen.kemdikbud.go.id 